\title{
A New Route for Direct Electroless Ni-P Plating on Magnesium Alloys
}

\author{
Tran Tan Nhat ${ }^{1, *}$, Bui Xuan Vuong ${ }^{2}$ \\ ${ }^{1}$ HCM City University of Food Industry \\ ${ }^{2}$ Sai Gon University, 273 An Duong Vuoong, 5 District, Ho Chi Minh City \\ Received 03 November 2016 \\ Revised 24 March 2017; Accepted 28 June 2017
}

\begin{abstract}
This report describes a new route for direct electroless Ni-P plating on magnesium alloys using nickel sulfate as the main salt component. The surface morphology, chemical composition and corrosion resistance of coatings were determined using SEM, EDX and electrochemical polarization techniques. Ni-P coatings with good corrosion resistance and high adhesion were obtained using this route and improved pretreatments. A mixture of $\mathrm{H}_{3} \mathrm{PO}_{4}$ and $\mathrm{HNO}_{3}$ was used as a pickling solution for $\mathrm{Mg}$ substrate pretreatment. A coarse surface was produced via the developed pickling procedure. A mechanical occlusive force is believed to exist between the coatings and the substrates. Twice activations, $\mathrm{K}_{4} \mathrm{P}_{2} \mathrm{O}_{7}$ and $\mathrm{NH}_{4} \mathrm{HF}_{2}$ as activation components, respectively, were applied for the pretreatment of magnesium alloy plating. An optimal F/O ratio on the Mg substrate surface was obtained by this pretreatment method. The activation film has insoluble partial fluorides which can depress the active points on substrate surface against the reaction of $\mathrm{Mg}$ with $\mathrm{Ni}^{2+}$ and $\mathrm{H}^{+}$in the plating bath. A highly stable bath with pH 5 buffer was identified. The advantages of the developed process include chromium-free, low fluoride, and high bath stability. It is applicable for the production of motorcycle part plating.
\end{abstract}

Keywords: Ni-P, electroless plating, Mg, surface, alloy.

\section{Introduction}

Magnesium (Mg) alloys are used in aerospace, automobile manufacturing and electronics industry due to a number of advantages such as conductive, antielectromagnetic interference, high intensity, etc[1-4]. However, the electrochemical potential of magnesium is very negative $(-2.36$ $\mathrm{V}$ vs. NHE), which leads to high chemical

\footnotetext{
*Corresponding author. Tel.: 84-912339787.

Email: nhathunan@yahoo.com

https://doi.org/10.25073/2588-1140/vnunst.4507
}

reactivity and poor corrosion resistance of magnesium alloys. This is one of the major reasons why the widespread applications of magnesium alloys have been greatly limited [57]. Hence, it is of great importance to increase the corrosion resistance of magnesium alloys by the surface treatments. Among several techniques, electroless nickel plating has exhibited increasing high popularity due to its excellent materials properties such as high hardness, wear resistance, corrosion resistance. This technique has attracted extensive interests from both the industry and other fields [8-13]. In electroless nickel plating, many researchers 
believe that the bath containing $\mathrm{Cl}^{-}$and $\mathrm{SO}_{2}{ }_{4}^{-}$ should be avoided since they enhance corrosion rather than nickel deposition. If alkaline nickel carbonate is used as the source of nickel, there are two main adverse causes. Firstly, HF concentration will inevitably increase in order to elevate the solubility of carbonate nickel. Excessive $\mathrm{F}^{-}$will produce $\mathrm{NiF}_{2}$ and $\mathrm{NaF}$ precipitation after several cycles of additions. Secondly, nickel carbonate is a very expensive nickel salt (nearly double the price of $\mathrm{NiSO}_{4}$ ), which increases the cost of production. The use of nickel sulfate as the main salt can not only reduce costs and improve economic efficiency, but also help to extend bath life. It is therefore much practical to develop the electroless nickel plating with $\mathrm{NiSO}_{4}$ main salt.

The heterogeneous microstructure of the magnesium alloy has the potential to make the alloy distribution on a substrate surface nonuniform, which makes the deposition of nickel difficult. Therefore, magnesium alloy is a kind of difficult-to-plate substrate [14]. Appropriate pretreatments of magnesium alloys are required for successful plating. Currently, typical pretreatment processes of electroless nickel plating on magnesium alloy mainly include (1) zinc immersion-cyanide copper plating, and (2) direct electroless nickel plating. The former process involves cyanide plating, and is thus harmful to humans and the environment [15]. The pretreatments in traditional direct electroless nickel often uses $\mathrm{CrO}_{3}$ and $\mathrm{HNO}_{3}$ for acid pickling and activation in $\mathrm{HF} . \mathrm{CrO}_{3}$ is highly toxic, $\mathrm{HF}$ is volatile and highly corrosive. The DOW process developed earlier era not only used the highly poisonous cyanide, but also the hexavalent chromium ions which were cancerous to human body. For a safe production it is therefore required to develop a green process for direct electroless nickel plating.

Electroless Ni-P plating solution is an unstable system in terms of thermodynamics. Some solid microparticles are often inevitably introduced in the plating bath. The microparticles with high specific area have some catalytic activity for the decomposition of the bath, which increases the production cost and causes environmental pollution [16]. Therefore, it is particularly necessary to develop high stability of the chemical bath. Some of the stabilizers commonly used in electroless nickel plating can be grouped into four types: (1) sulfur compounds, such as thiourea and mercapto benzothiazole (MBT); (2) oxygenated compounds, such as $\mathrm{KIO}_{3}$ and $\mathrm{MoO}_{3}$; (3) heavy metal ions, such as $\mathrm{Pb}^{2+}$ and $\mathrm{Cd}^{2+}$; and (4) water-soluble organic compounds, such as dimethyl succinate and fumarate. Since lead and cadmium are toxic, they have gradually been abandoned. Thiourea and iodate as stabilizers in the electroless nickel plating on magnesium alloy are wise choices [17]. There is a clear need for the investigation of optimum dosage of the stabilizers need, which is an important focus of the work reported herein.

\section{Experiments}

(1) Specimen preparation: The substrates used for plating in the experiments were prepared from a plain die cast of magnesium alloy AZ91D(rectangular coupons of size $30 \times$ $20 \times 2 \mathrm{~mm}^{3}$ ). The specimen surface was first grounded on a grinding wheel and then further leveled by 1200 grade SiC wet emery paper. All the experiments were performed at least 3 times in order to confirm the reproducibility of the results.

(2) Plating rate detection: The plating rate ( $v: \mu \mathrm{m} \cdot \mathrm{h}^{-1}$ ) was determined by weighing method and can be calculated according to the following equation:

$$
\mathrm{v}=\frac{10\left(\mathrm{w}_{\mathrm{t}}-\mathrm{w}_{0}\right)}{\mathrm{A}_{\mathrm{s}} \rho \mathrm{t}}
$$

where $w_{t}(\mathrm{mg})$ is the mass of the specimen plated for time $t, w_{0}(\mathrm{mg})$ is the initial mass of specimen, $A_{\mathrm{s}}\left(\mathrm{cm}^{2}\right)$ is the surface area of specimen, $\rho\left(\mathrm{g} \cdot \mathrm{cm}^{-3}\right)$ is the density of Ni-P coating, and $t(\mathrm{~h})$ is the plating duration. 
(3) Bath stability characterization: Ryabinina et al. advocated that the estimation of the bath stability is reasonable by considering the stability constant, $b$, defined as the ratio of the weight of $\mathrm{Ni}$ in a coating to the total weight of metal deposited from the EN solution [19]. The equation can be expressed as follows:

$$
b=\frac{m_{1}}{m_{2}} \times 100 \%
$$

where $m_{1}(\mathrm{~g})$ is the weight of $\mathrm{Ni}$ in the coating, $m_{2}(\mathrm{~g})$ is the total weight of Ni deposited.

(4) Concentration detection and electrochemical measurement: The concentration of hypophosphite was estimated by an iodometric back-titration method [20]. Potentiodynamic polarization experiments were carried out in a $500 \mathrm{~cm}^{3}$ glass cell containing $300 \mathrm{~cm}^{3} 3.5 \% \mathrm{NaCl}$ aqueous solution at a scan rate of $1 \mathrm{mV} \cdot \mathrm{s}^{-1}$. An freshly EN deposit was used as the working electrode in electrochemical measurements, and the electrode was sealed by epoxy resin, leaving a $1 \times 1 \mathrm{~cm}^{2}$ effective working area. The auxiliary and reference electrodes were $\mathrm{Pt}$ foil and saturated calomel electrode (SCE), respectively.

(5) Characterization of coating morphology and composition: A FEI Quanta 200 scanning electron microscope (SEM) was employed to examine the surface and crosssection morphologies of the immersion coating.
The Ni and P content of the EN deposits were determined using a Genesis XM2 Energy dispersive X-ray (EDX) analyzer attached to the SEM microscope.

\section{Results and discussion}

\subsection{Baths with different main salts}

In order to investigate the feasibility of plating bath using nickel sulfate as the main salts, the baths were composed of the main salt of nickel sulfate and nickel carbonate, as shown in Table1. The pretreatments involved the use of chromate and hydrofluoric acid. The deposition rate and the quality of coatings for two baths are shown in Table 2. The qualities of the coatings obtained in the two baths were evaluated through immersing in $3.5 \mathrm{wt} . \% \mathrm{NaCl}$ solution for 2 hours. After $2.5 \mathrm{~h}$ immersion, corrosion spots were observed on the coatings deposited in the nickel carbonate bath, whereas no corrosion spots were observed on the coating deposited in the nickel sulfate bath even though the coating was immersed for $3 \mathrm{~h}$. It is therefore concluded that the electroless nickel in the bath containing nickel sulfate as main salts is more successful than that in the nickel carbonate bath.

Table 1. Two main salts bath and plating processes

\begin{tabular}{llll}
\hline \multicolumn{3}{l}{ Nickel sulfate bath } & Nickel carbonate bath \\
\hline $\mathrm{NiSO}_{4} \cdot 6 \mathrm{H}_{2} \mathrm{O}$ & $20 \mathrm{~g} \cdot \mathrm{dm}^{-3}$ & $\mathrm{NiCO}_{3} \cdot 2 \mathrm{Ni}(\mathrm{OH})_{2} \cdot 4 \mathrm{H}_{2} \mathrm{O}$ & $10 \mathrm{~g} \cdot \mathrm{dm}^{-3}$ \\
$\mathrm{HF}(40 \%)$ & $12 \mathrm{~cm}^{3} \cdot \mathrm{dm}^{-3}$ & $\mathrm{HF}(40 \%)$ & $12 \mathrm{~cm}^{3} \cdot \mathrm{dm}^{-3}$ \\
$\mathrm{C}_{6} \mathrm{H}_{8} \mathrm{O}_{7} \cdot \mathrm{H}_{2} \mathrm{O}$ & $5 \mathrm{~g} \cdot \mathrm{dm}^{-3}$ & $\mathrm{C}_{6} \mathrm{H}_{8} \mathrm{O}_{7} \cdot \mathrm{H}_{2} \mathrm{O}$ & $5 \mathrm{~g} \cdot \mathrm{dm}^{-3}$ \\
$\mathrm{NH}_{4} \mathrm{HF}_{2}$ & $10 \mathrm{~g} \cdot \mathrm{dm}^{-3}$ & $\mathrm{NH}_{4} \mathrm{HF}_{2}$ & $10 \mathrm{~g} \cdot \mathrm{dm}^{-3}$ \\
$\mathrm{NH}_{3} \cdot \mathrm{H}_{2} \mathrm{O}(25 \%)$ & $30 \mathrm{~cm} \cdot \mathrm{dm}^{-3}$ & $\mathrm{NH}_{3} \cdot \mathrm{H}_{2} \mathrm{O}(25 \%)$ & $30 \mathrm{~cm}^{3} \cdot \mathrm{dm}^{-3}$ \\
$\mathrm{NaH}_{2} \mathrm{PO}_{2} \cdot \mathrm{H}_{2} \mathrm{O}$ & $20 \mathrm{~g} \cdot \mathrm{dm}^{-3}$ & $\mathrm{NaH}_{2} \mathrm{PO}_{2} \cdot \mathrm{H}_{2} \mathrm{O}$ & $20 \mathrm{~g} \cdot \mathrm{dm}^{-3}$ \\
$\mathrm{H}_{2} \mathrm{NCSNH}_{2}$ & $1 \mathrm{mg} \cdot \mathrm{dm}^{-3}$ & $\mathrm{H}_{2} \mathrm{NCSNH}_{2}$ & $1 \mathrm{mg} \cdot \mathrm{dm}^{-3}$ \\
$\mathrm{pH}$ & 4.0 & $\mathrm{pH}$ & $6.5 \pm 1.0$, \\
Plating temperature & $75-85{ }^{\circ} \mathrm{C}$ & Plating temperature & $80 \pm 2{ }^{\circ} \mathrm{C}$ \\
Plating time & $60 \mathrm{~min}$ & Plating time & $60 \mathrm{~min}$ \\
\hline
\end{tabular}




\subsection{Pretreatment process}

Pretreatment in direct electroless nickel plating generally includes ultrasonic cleaning, alkaline pickling, and pickling and activation. The former two steps were to clean the oil and grease on $\mathrm{Mg}$ substrates. The purpose of acid pickling is to remove the loose surface layer of substrate, including oxides, hydroxides, passivation film embedded in the dust, so as to ensure that the substrate can reacts with the activation solution in the next step. One purpose of the activation was to form catalytic center for $\mathrm{Ni}$ deposition on $\mathrm{Mg}$ substrate.
Another purpose was to enable the substrate to produce an insoluble film (often $\mathrm{MgF}_{2}$ ) for efficiently protecting the substrate from corrosion when the specimen was immersed in the bath.

A chromium-free pretreatment process was developed in our investigation by using phosphoric acid plus nitric acid, pyrophosphate, and ammonium hydrogen fluoride. The composition and condition of the developed pretreatment process is compared with conventional pretreatment process containing chromium, as shown in Table 3.

Table 2. Qualities of coatings obtained from the two baths

\begin{tabular}{|c|c|c|c|c|c|}
\hline No. & Bath type & Rate $/ \mu \mathrm{m} \cdot \mathrm{cm}^{-2} \cdot \mathrm{h}^{-1}$ & $\begin{array}{l}\text { Coating } \\
\text { morphology }\end{array}$ & $\begin{array}{l}\text { Corrosion } \\
\text { time } / \mathrm{h}\end{array}$ & $\begin{array}{l}\text { Corrosion } \\
\text { spots } / \mathrm{cm}^{-2}\end{array}$ \\
\hline 1 & Nickel sulfate bath & 33.16 & $\begin{array}{l}\text { luculent and } \\
\text { compact }\end{array}$ & $\begin{array}{l}2.0 \\
2.5 \\
3.0\end{array}$ & $\begin{array}{l}0 \\
0 \\
0.13\end{array}$ \\
\hline 2 & $\begin{array}{l}\text { Nickel carbonate } \\
\text { bath }\end{array}$ & 17.36 & $\begin{array}{l}\text { luculent and } \\
\text { compact }\end{array}$ & $\begin{array}{l}2.0 \\
2.5 \\
3.0\end{array}$ & $\begin{array}{l}0 \\
0.33 \\
1.03 \\
\end{array}$ \\
\hline
\end{tabular}

Table 3. Pretreatment solution and operation condition

\begin{tabular}{|c|c|c|c|}
\hline $\begin{array}{l}\text { Pickling- } \\
\text { activation (PA) }\end{array}$ & Process name & Solution composition & $\begin{array}{l}\text { Operation } \\
\text { condition }\end{array}$ \\
\hline \multirow[t]{3}{*}{ PA1 } & Pickling 1 & $\mathrm{CrO}_{3} \quad 125 \mathrm{~g} \cdot \mathrm{dm}^{-3}$ & Room temperature \\
\hline & & $\mathrm{HNO}_{3}(68 \%) \quad 110 \mathrm{~cm}^{3} \cdot \mathrm{dm}^{-3}$ & $30-60 \mathrm{~s}$ \\
\hline & Activation 1 & $\mathrm{HF}(40 \%) \quad 385 \mathrm{~cm}^{3} \cdot \mathrm{dm}^{-3}$ & $\begin{array}{l}\text { Room temperature } \\
8 \sim 19 \text { min }\end{array}$ \\
\hline \multirow[t]{7}{*}{ PA2 } & Pickling 2 & $\mathrm{HNO}_{3}(68 \%) \quad 30 \mathrm{~g} \mathrm{dm}^{-3}$ & Room temperature \\
\hline & & $\mathrm{H}_{3} \mathrm{PO}_{4}(85 \%) \quad 605 \mathrm{~cm}^{3} \cdot \mathrm{dm}^{-3}$ & $30-40 \mathrm{~s}$ \\
\hline & Activation 2 & $\mathrm{~K}_{4} \mathrm{P}_{2} \mathrm{O}_{7} \quad 120 \sim 200 \mathrm{~g} \cdot \mathrm{dm}^{-3}$ & $70 \pm 5^{\circ} \mathrm{C}$ \\
\hline & & $\mathrm{Na}_{2} \mathrm{CO}_{3} \quad 10 \sim 30 \mathrm{~g} \cdot \mathrm{dm}^{-3}$ & $2 \sim 3 \mathrm{~min}$ \\
\hline & & $\mathrm{KF} \cdot 2 \mathrm{H}_{2} \mathrm{O} \quad 11 \mathrm{~g} \cdot \mathrm{dm}^{-3}$ & \\
\hline & Activation 3 & $95 \mathrm{~g} \cdot \mathrm{dm}^{-3}$ & Room temperature \\
\hline & & $180 \mathrm{~g} \cdot \mathrm{dm}^{-3}$ & $2 \sim 3 \min$ \\
\hline
\end{tabular}

The morphologies and compositions of the etched substrate surface obtained by the pretreatment process are shown in Figure 1 and Table 4.

Figure 1 shows that the crude substrates were etched. The crude surface could increase the mechanical occlusive force between the substrate and the coating, leading to an increased adhesion. According to the $\mathrm{F}$ and $\mathrm{O}$ contents in Table 4, the activation films containing less $\mathrm{MgF}_{2}$ and more $\mathrm{Mg}(\mathrm{OH})_{2}$ by the improved pretreatment were better than that by the conventional pretreatment. However, higher $\mathrm{O}$ content can provide more active dots on the exposed $\mathrm{Mg}$ substrate via $\mathrm{Mg}(\mathrm{OH})_{2}$ dissolution, which is propitious to replace nickel in the plating bath and increases the initial deposition rate. 

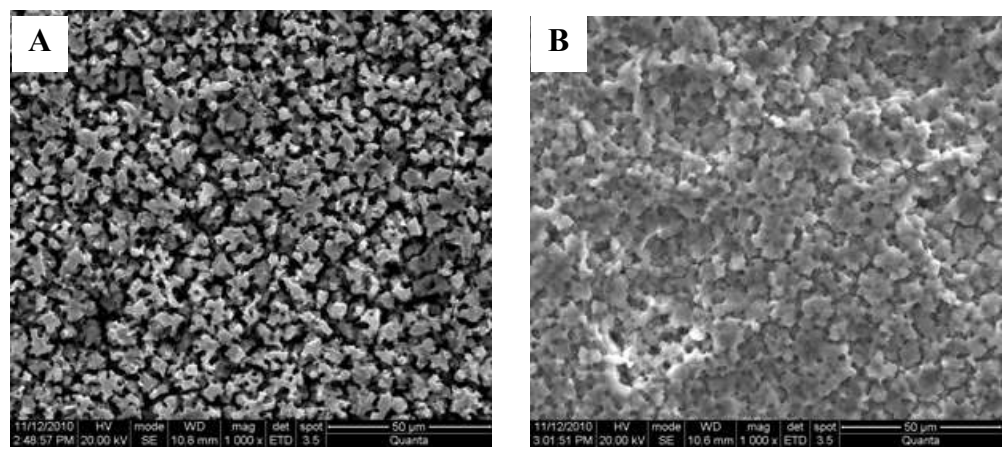

Figure 1. Morphologies of two substrates obtained via pretreatment processes (A) PA1 and (B) PA2.

Table 4. EDX composition of the activation films on AZ91D magnesium alloys (atom \%)

\begin{tabular}{llllll}
\hline Pretreatment & $\mathrm{O}$ & $\mathrm{F}$ & $\mathrm{Mg}$ & $\mathrm{Al}$ & $\mathrm{Na}$ \\
\hline PA1 & 2.61 & 9.81 & 83.78 & 3.80 & - \\
PA2 & 3.09 & 3.71 & 86.34 & 6.18 & 0.68 \\
\hline
\end{tabular}

The morphologies and characteristics of the coatings acquired by the two pretreatment processes are shown in Figure 2 and Table 5, respectively. The compact coatings with high $\mathrm{P}$ content were obtained via the two pretreatment processes. We did not observe corrosion spots
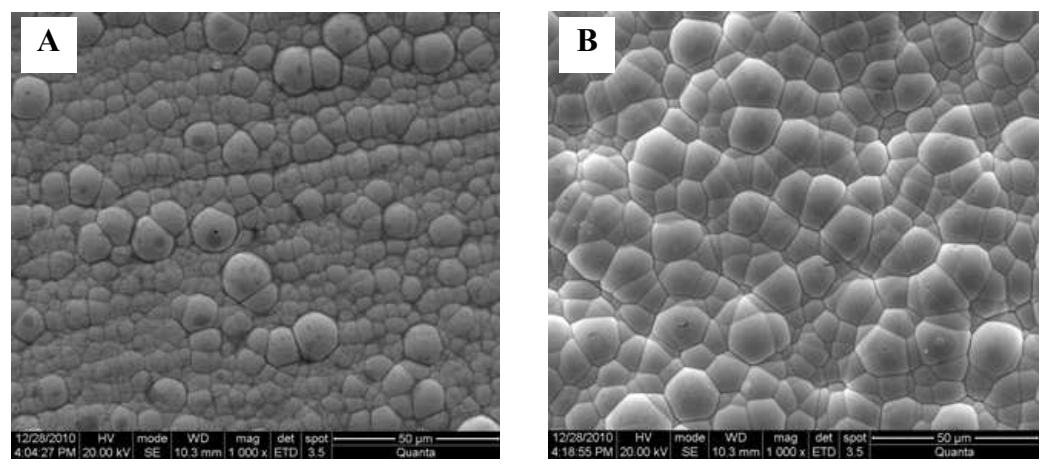

Figure 2. SEM images of the two coatings obtained via (A)PA1 and (B)PA2.

Table 5. Corrosion resistance and phosphorus content of two Ni-P coatings

\begin{tabular}{lcc}
\hline Pretreatment & Corrosion spots $/ \mathrm{cm}^{-2}$ & Adhesion \\
\hline PA1 & 0 & $\Delta$ \\
PA2 & 0 & $\mathrm{O}$ \\
\hline
\end{tabular}

Note: " $\Delta$ " indicates that sometimes small plating swelling occurs but no peeling off. "O" represents good quality plating without swelling and peeling- off. 
Potentiodynamic polarization curves for Ni$\mathrm{P}$ coating and bare $\mathrm{Mg}$ substrate were determined in $3.5 \mathrm{wt} . \% \mathrm{NaCl}$ solution at room temperature, as shown in Figure 3. Corrosion potentials of the coatings are increased and the corrosion currents are decreased compared with

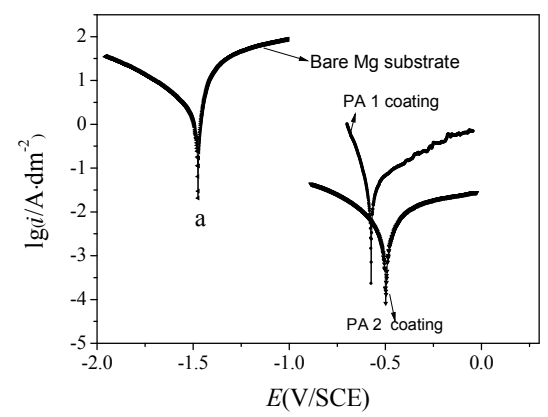

Figure 3. Polarization curves of the two coatings and bare $\mathrm{Mg}$ substrate in $3.5 \% \mathrm{NaCl}$ solution.

\subsection{Bath stability}

The effects of various stabilizers on the deposition rate from the bath in Table 1 containing nickel sulfate as the main salt are shown in Figure 4. The deposition rate was firstly increased. It reached a maximum value at $0.5 \mathrm{mg} \cdot \mathrm{dm}^{-3}$ thiourea, and then decreased as thiourea continued to increase. Han et al [21] suggested that thiourea may participate in the formation of the reactive intermediate and facilitate the oxidation of hypophosphite ion through adsorption on the catalytic metal surface, which thereby results in the acceleration of EN plating. However, the deposition rate was decreased under a higher concentration as the strong adsorption of thiourea on the metal surface depressed the active sites. The dependence of the deposition rate on the potassium iodate concentration was similar to that using thiourea, but the maximum rate was found at $5 \mathrm{mg} \cdot \mathrm{dm}^{-3}$ potassium iodate. The dependence of bath stability constant $(b)$ on concentration of the stabilizers is shown in Figure 5. The situation is similar to that in Figure 4. It indicates that the maximum $b$ is those for the bare Mg substrate. Moreover, the corrosion potential of the coating obtained by the developed pretreatment process is more positive than that by the traditional pretreatment process.

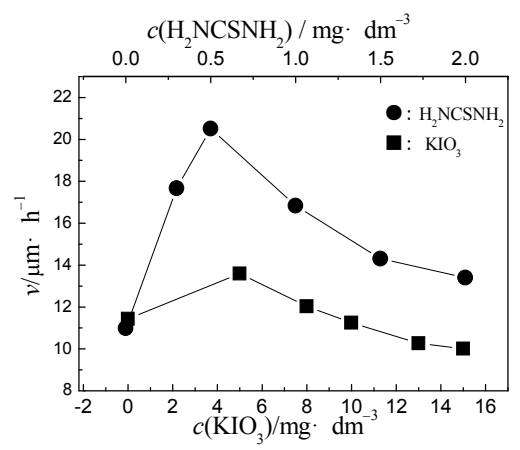

Figure 4. Plating rate at various concentrations of the stabilizers.

$86.32 \%$ at $0.5 \mathrm{mg} \cdot \mathrm{dm}^{-3}$ for thiourea, and $82.45 \%$ at $5 \mathrm{mg} \cdot \mathrm{dm}^{-3}$ for potassium iodate. More nickel ions are reduced in bath for potassium iodate, leading to a decrease of the stability constant. In comparison, thiourea is a more adaptive bath stabilizer than potassium iodate.

The dependence of the deposition rate and bath stability constant on $\mathrm{pH}$ value at 0.5 $\mathrm{mg} \cdot \mathrm{dm}^{-3}$ thiourea bath is shown in Figure 6 . The deposition rate is gradually increased with $\mathrm{pH}$ from 3.5 to 6.5 . However, a maximum $b$ is found at $\mathrm{pH} 5.0$ from $b$ curve in Figure 6.

The dependences of the deposition rate and stability constant $(b)$ on temperature are shown in Figure 7. The deposition rate was found to speed up with temperature. However, the stability constant reached the maximum at 82 ${ }^{\circ} \mathrm{C}$. The increased temperature plating leads to the bath's instability.

From the above discussion, we conducted that electroless nickel plating in $\mathrm{pH} 5.0$ bath containing $0.5 \mathrm{mg} \cdot \mathrm{dm}^{-3}$ thiourea at $82{ }^{\circ} \mathrm{C}$ has an optimal performance. 


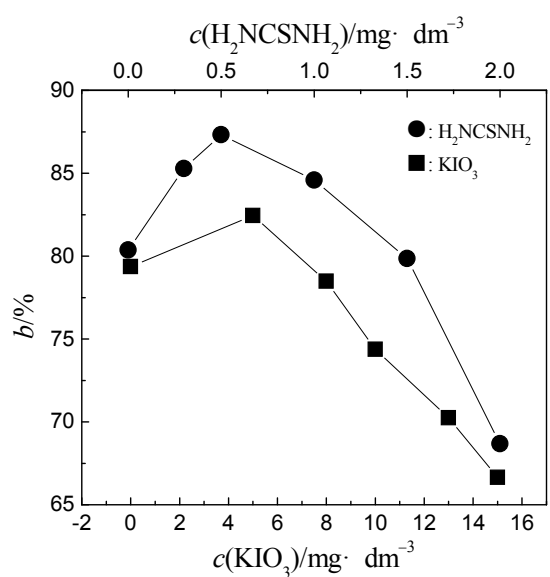

Figure 5. Dependence of stability constant on the concentration of the stabilizers in the bath.

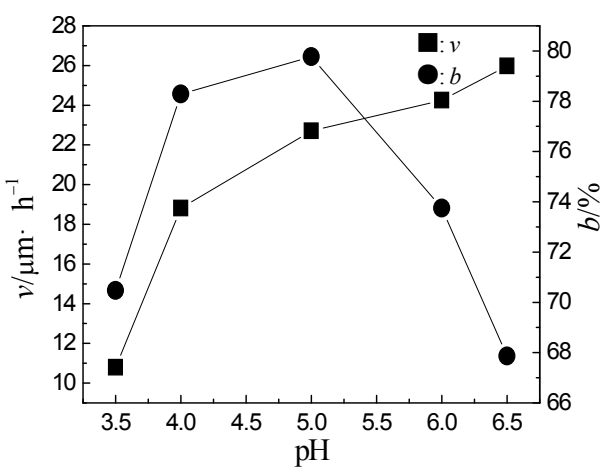

Figure 6. Dependences of plating rate and bath stability constant on $\mathrm{pH}$ value.

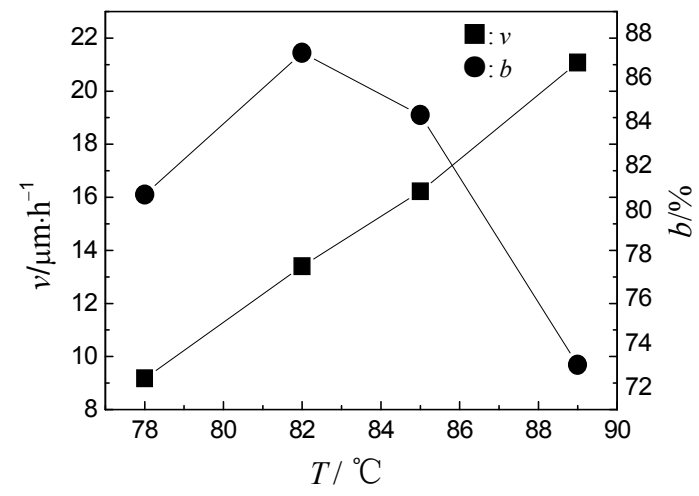

Figure 7. Dependence of plating rate and bath stability on temperature.

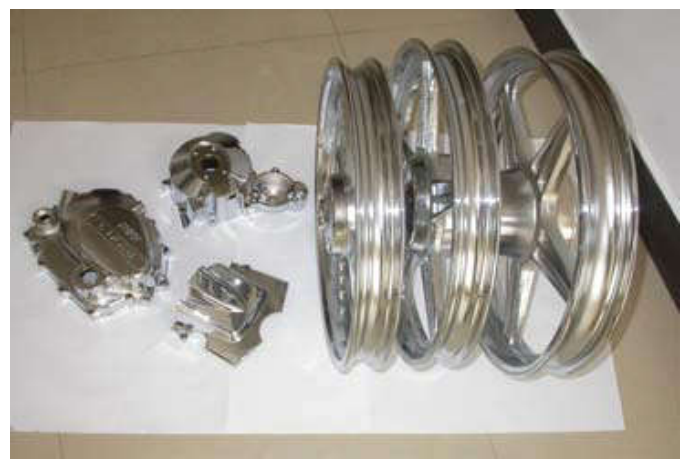

Figure 8. Photo of the electroplating products of $\mathrm{Mg}$ hub and motor engine shell. 


\subsection{Application of the electroless nickel plating process in electroplating production}

Magnesium alloy wheels and other parts of vehicles usually have irregular shapes. It is difficult to obtain uniform coating via electroplating for complex work pieces. However, a uniform coating on $\mathrm{Mg}$ substrate can be obtained by electroless preplating. Thus, this coating can enable us to successfully conduct $\mathrm{Cu} / \mathrm{Ni} / \mathrm{Cr}$ composite electroplating. The test results indicated that the composite coatings of $\mathrm{Cu} / \mathrm{Ni} / \mathrm{Cr}$ on the wheel hub and motor engine shell products of the magnesium alloys were indeed successfully electroplated by the electroless nickel preplating process, as shown in Figure 8. The composite layer coatings showed a high adhesion through thermal shock testing and scribe grid testing, as shown in Table 8. The corrosion resistance of the electroplated products reached to Grade 9 (Chinese Standard GB/T6461-2002) by salt spray testing.

\section{Conclusions}

In conclusion, effective pretreatment processes have been developed. The main characteristics of these processes include acid pickling in nitric acid and phosphoric acid, single activation in potassium pyrophosphate, and double activation in ammonium hydrogen fluoride. In addition, the pretreatment involved chromium-free and environment-friendly processes. The developed bath using nickel sulfate as the main salt not only showed high stability, but also good coating with high adhesion and excellent corrosion resistance. The green production of electroless nickel plating on magnesium alloys has important implications for generating enormous economic and social impacts.

\section{References}

[1] J E Gray, B Luan. J. Alloys Compd., 2002, 336: 88-113.

[2] R Ambat, W Zhou. Surf. Coat. Technol., 2004, 179, 124-134.

[3] BL Mordike, T Ebert. Mater. Sci. Eng A., 2001, 302, 37-45.

[4] H Friedrich, S Schumann. J. Mater. Process. Technol., 2001, 117, 276-281.

[5] E Aghion, B Bronfin. J. Mater. Process. Technol., 2001, 117, 381-385.

[6] GL Song, A Atrens. Adv. Eng. Mater., 1999, 1, 11-33.

[7] GL Makar, J Kruger. Int. Mater. Rev., 1993, 38, 138-153.

[8] FH Froes, D Eliezer, E Aghion. Adv. Perf. Mater., 1998, 50, 30-34.

[9] GO Mallory, JB Hajdu. Electroless Plating: Fundamentals and Applications, 1990, Orlando, FL, AESF Publishing.

[10] H Yan. New Techniques in Electroless Ni and Composite Plating, 2001, Beijing, Industry of National Defense Press.

[11] A Brenner, GE Riddel. J. Res. Natl. Bur. Stand., 1946, 37, 31.

[12] W Riedel. Electroless Ni Plating, 1991, ASM International, Finishing Publications.

[13] CD Gu, JS Lian, GY Li, LY Niu, ZH Jiang. Surf. Coat. Technol., 2006, 200, 5956-5962.

[14] H Zao, Z Huang, J.Cui. Surf. Coat. Technol., 2007, 202, 133- 139.

[15] A K Sharma, M R Suresh, H Bhojraj. Met. Finish., 1998, 96, 10-18.

[16] W Riedel. Electroless Nickel Plating, Finishing Publications Ltd., Hertfordshire, 1991.

[17] W J Cheong, B L Luan, D W Shoesmith. Appl. Surf. Sci., 2004, 229, 282-300.

[18] Z H Xie, G Yu, B H Hu. Appl. Surf. Sci., 2011, 257, 5025-5031.

[19] EI Ryabinina, NV Sotskaya, KS Shikhaliev. Russ. J. Appl. Chem., 1999, 72, 1932-1935.

[20] NK Dirjal, AH Kenneth, BW Peter. Anal. Chim. Acta, 1994, 290,287-293.

[21] K P Han, J L Fang., Met. Finish., 1997, 95, 73-75. 


\title{
Phương pháp mới mạ hóa học trực tiếp Ni-P trên hợp kim Mg
}

\author{
Trần Tấn Nhật ${ }^{1}$, Bùi Xuân Vương ${ }^{2}$ \\ ${ }^{1}$ Đại học Công nghiệp Thục phẩm Thành phố Hồ Chỉ Minh \\ ${ }^{2}$ Đại học Sài Gòn, 273 An Duoong Vuoong, Quận 5, Thành phố Hồ Chí Minh
}

Tóm tắt: Nghiên cứu này mô tả một hướng mới trong quá trình mạ hóa học trực tiếp Ni-P trên hợp kim magiê bằng muối niken sunfat là thành phần chính. Hình dạng bề mặt, thành phần hóa học và khả năng kháng ăn mòn của lớp phủ được xác định bằng SEM, EDX và các kỹ thuật phân cực điện hóa. Lớp phủ Ni-P có khả năng chống ăn mòn tốt, độ bám dính cao cũng như cải thiện được vấn đề tiền xử lý trước khi mạ. Hỗn hợp dung dịch $\mathrm{H}_{3} \mathrm{PO}_{4}$ and $\mathrm{HNO}_{3}$ được dùng để làm chất tiền xử lý để tẩy rửa bề mặt hợp kim $\mathrm{Mg}$. Một bề mặt thô của chất nền được tạo ra và làm cho lực liên kết giữa lớp mạ và chất nền tăng lên. Hoạt hóa bề mặt hợp kim hai lần bằng các dung dịch $\mathrm{K}_{4} \mathrm{P}_{2} \mathrm{O}_{7}$ và $\mathrm{NH}_{4} \mathrm{HF}_{2}$ trước khi mạ. Bằng phương pháp xử lý này đã thu được tỷ lệ $\mathrm{F} / \mathrm{O}$ tối ưu được tạo ra trên bề mặt hợp kim Mg. Màng hoạt hóa có chứa một phần ion Flo không hòa tan, nó làm giảm các trung tâm hoạt động trên bề mặt hơp kim $\mathrm{Mg}$ và ngăn cản phản ứng giữa $\mathrm{Mg}$ với $\mathrm{Ni}^{2+}$ và $\mathrm{H}^{+}$trong bể mạ. Dung dịch mạ rất ỗn định với $\mathrm{pH}=5$. Những ưu điểm mà phương pháp này đem lại đó là: lượng crom tự do, flo thấp và độ ốn định của dung dịch mạ cao.

Tù khóa: Ni-P, mạ hóa học, Mg, bề mặt, hợp kim. 